\title{
Universiteit
}

Leiden

The Netherlands

\section{Review of Facts in Administrative Law Procedures; A European Community Law Perspective}

Schuurmans, Y.E.

\section{Citation}

Schuurmans, Y. E. (2008). Review of Facts in Administrative Law Procedures; A European Community Law Perspective. Review Of European Administrative Law, 1(1), 5-34. Retrieved from https://hdl.handle.net/1887/13616

Version: $\quad$ Not Applicable (or Unknown)

License: $\quad$ Leiden University Non-exclusive license

Downloaded from: $\quad$ https://hdl.handle.net/1887/13616

Note: To cite this publication please use the final published version (if applicable). 
Articles 



\title{
Review of Facts in Administrative Law Procedures; A European Community Law Perspective
}

\author{
Dr. Y.E. Schuurmans \\ Assistant Professor of Law, Administrative and Constitutional Law, \\ Leiden University
}

\begin{abstract}
Fact-finding is invariably a part of administrative decisionmaking. In administrative law procedures the courts in general refrain from repeating this fact-finding process but, instead, review the fact-finding procedure. This contribution seeks to examine the requirements placed by the Community courts on the national courts' reading of the facts in matters involving EC law. In this context, a parallel will be drawn with the standards upheld by the Community courts as regards their own review of facts, in the context of direct appeals against decisions taken by the Community institutions. It will be examined to what extent this review by the Community courts agrees or contrasts with the review performed in Dutch administrative law courts. A more uniform method of reviewing facts could enhance the harmonisation and implementation of EC law.
\end{abstract}

\section{Introduction ${ }^{\mathrm{I}}$}

For the implementation of European law it is of great importance how and with which intensity national courts review whether a national decision agrees with EC law. An important part of this review concerns the factual findings made by the decision-maker, an administrative authority. Dutch administrative law courts and fact-finding, though, make a difficult combination. On the one hand, the principle of the dispensation of justice on the basis of substantive truth is of paramount importance. On the other hand, there is often only limited room for truth finding during the legal proceedings and the courts' decisions hardly ever include a final opinion on the facts. In general, Dutch administrative law courts usually only review whether the investigation carried out by the administration has been sufficient, on the basis of principles such as the requirement of due care and the duty to state reasons. In that case the courts themselves do not have to carry out all kinds of complicated factual assessments.

If we consider this interpretation of duties by the Dutch administrative law courts from the European law perspective, a few question marks are in

This article is based on a publication in Dutch: 'De toetsing van de feitenvaststelling in Europees perspectief', in: T. Barkhuysen, W. den Ouden \& E. Steyger (eds.), Europees recht effectueren, Alphen aan den Rijn: Kluwer 2007, p. II5-I42. Translation costs were partly funded by the KNAW Vertaalfonds. 
order. Do the courts at present actually offer private individuals enough legal protection, so that they can effectuate their rights derived from EC law and do they sufficiently check if the administration has complied with EC law? Should they not review fact-finding more intensively and render a final opinion thereon? Arguably, it is only when the facts in dispute have been established definitively that it is possible to determine whether or not a European legal rule has been applied correctly.

This contribution seeks to examine the requirements placed by the European Court of Justice (ECJ) and the Court of First Instance (CFI) on the national courts' opinion on the facts in matters involving Community law. In this context, a parallel will be drawn with the requirements placed by the Community courts on their own review of facts in assessing a direct appeal against decisions taken by the Community institutions. It will be examined to what extent this review by the Community courts agrees or contrasts with the Dutch review. If we were to find out that our national review of the factfinding agrees to a large extent with the review by the Community courts, we have to worry little about the danger of future infringements. However, if there turn out to be differences between the two methods of review, the question is whether there is sufficient justification for this. An adjustment of national review might lead to a more effective implementation of Community law. ${ }^{2}$ In this respect a better understanding of methods of review of factfinding serves a broader goal. The harmonization of substantive law does not as such guarantee the uniform application of harmonized law. Rules of evidence, like the evaluation of evidence, the standard of proof and the burden of proof, in the various procedural laws of the Member States will highly affect the way a norm is applied. ${ }^{3}$ A more uniformed review method of facts could enhance the implementation of Community law.

Section two and three describe the way in which the Dutch administrative law courts review assessments of the facts in administrative decisions. Attention is also paid to the debate in academic literature. Section four sets out this Dutch debate from the EC law perspective. Section five and six deal with the standard of review of facts applied by the Community courts. A conclusion and some final observations are laid down in section seven.

2 This could be called the 'PF-method' (proactive and facilitating: the legal implementation, application and enforcement of European law may be simplified and facilitated by means of general provisions of national administrative law even without European law forcing to this), see P.C. Adriaanse, T. Barkhuysen, W. den Ouden \& Y.E. Schuurmans, 'Effective Implementation of European Community Law. A Facilitating Role of Dutch General Administrative Law', [2008] Transylvanian Review of Administrative Sciences, nr. 22E, p. 5-33.

3 Mina Hattaka \& Hannu Tapani Klami, 'Evidence and European Law', [1994] Tidskrift utgivenav Juridiska Föreningen i Finland, p. 551-56r. 


\section{Dutch Administrative Law Courts, Fact-Finding and the Principle of Due Care}

\section{Dutch administrative law courts have various means to} investigate the facts during judicial proceedings. If the parties disagree about the facts, the court may investigate the facts itself or order the parties to submit additional proof. Various articles from Chapter 8 of the General Administrative Law Act (GALA) make it clear that the administrative law courts are independently competent to investigate and establish facts. Appellate courts have jurisdiction over the facts as well.

Research has shown, however, that the administrative law courts exercise this competence only sparingly. ${ }^{4}$ As a general rule, the administrative law court that is required to render an opinion on disputed facts does not institute its own investigation. A judicial request addressed to the parties to submit additional proof for their assertions is also quite exceptional. These findings may be explained in part on the basis of practical arguments. A great deal of information is gathered in the context of the preparation of the contested decision by the administrative authority. The evidence already available will frequently be sufficient to allow the court to render an opinion on the facts. Moreover, the planning of cases does not, as a general rule, take account of the possibility that the case may be suspended due to the necessity of a further investigation of the facts. ${ }^{5}$

In addition, there is a more principled argument. Case law of various Dutch administrative law courts clearly shows that judges believe it is primarily up to the administrative authority to investigate the facts. This view is in line with Article 3:2 of the GALA, in which the administrative authority is instructed to gather all relevant information in preparing a decision. ${ }^{6}$ If it turns out in the process that the administrative authority has failed to do so properly, the court invariably considers this to be an argument not to carry out its own investigation. The administrative law courts do not consider it to be their task to remedy the administrative authority's defective investigation of the facts. ${ }^{7}$ Because the review against Article 3:2 of the GALA is usually leading, the courts primarily answer the question whether the administrative authority has carried out a careful investigation of the facts. The judicial review of the fact-finding concentrates mainly on the question whether the procedure has been careful and not whether the facts found are correct in the courts' opinion.

4 T. Barkhuysen, L.J.A. Damen et al., Feitenvaststelling in beroep, Den Haag: Boom Juridische uitgevers 2007, p. I99 et seq.

5 Barkhuysen, Damen et al. (2007), p. 213.

6 See for an overall view on the obligations arising from Article 3:2 GALA in a European law perspective: Jan H. Jans, 'The Consequential Effect of European Law in Respect of the Requirement of Due Care', [2007] REALaw, p. 63-72.

7 Barkhuysen, Damen et al. (2007), p. 63 et seq. 
Another complication is that new evidence is not always accepted. Especially when the interested party bore the burden of proof when applying for a decision, it is not always allowed to supply new evidence in the judicial procedure. If an administrative law judge would evaluate this piece of evidence, he might interfere with the power of the executive. After all a judge is not permitted to issue an executive decision.

The described interpretation of the courts' duty is recognised particularly in the case law of the Raad van State (Administrative Law Division of the Council of State). ${ }^{8} 9$

The administrative law courts' role in fact-finding has received a great deal of attention in academic literature. There is an acute awareness of the tension between the rule of law and the administration of justice on the basis of substantive truth on the one hand, and the courts' limited role in a state based on the separation of powers on the other hand. ${ }^{\text {I0 }}$ There are differing opinions whether the administration may have discretion when assessing facts. As will be seen in section five, various arguments in this Dutch debate are also put forward when discussing the intensity of review of facts in Community law.

Traditionally, most academics are of the opinion that an administrative authority lacks discretion in the fact-finding process and that administrative law courts can fully review the facts. The courts bear their own responsibility for establishing the facts in such a manner that these correspond with the substantive truth as much as possible. If it turns out in the process that the facts are different from those established in the administrative authority's decision, the decision cannot be regarded as lawful. For the purposes of effective legal protection, the courts must be able to form their own opinion about the facts. ${ }^{\text {II }}$ Under certain circumstances discretion in inter-

8 The Raad van State is the highest national administrative law court charged with the general jurisdiction in administrative law cases in the Netherlands. It deals with both questions of law and of fact. There are also several specialized administrative law courts. See www.rechtspraak.nl/information+in+english. The College van Beroep voor het bedrijfsleven (Trade and Industry Appeals Tribunal) rules on disputes in the area of social-economic administrative law, e.g. on appeals in competition law.

9 E.J. Daalder \& M. Schreuder-Vlasblom, 'Balanceren boven nul', [2000] NTB, p. 2I4-22I; Y.E. Schuurmans, Bewijslastverdeling in het bestuursrecht. Zorgvuldigheid en bewijsvoering bij beschikkingen (PhD thesis Amsterdam, VU), Deventer: Kluwer 2005, p. 273-276; R.J.G.M. Widdershoven, 'De ABRS en de toetsing aan het EG-recht', in: W. den Ouden (ed.), Staatssteun en de Nederlandse rechter, Deventer: Kluwer 2005, p. 40-43.

ro See on the position of discretion between the principles of the rule of law and the separation of powers: Roberto Caranta, 'On Discretion', in: Sacha Prechal \& Bert van Roermund (eds.), The Coherence of EU Law: The Search for Unity in Divergent Concepts, Oxford: Oxford University Press 2008, p. I85-215.

II R.H. de Bock, 'Waarheidsvinding in het bestuursrecht', in: Het procesrecht en de waarheidsvinding (NVvP-reeks I3), Den Haag: Boom Juridische uitgevers 200I, p. 44; J.E.M. Polak 
pretation may extend to the question how facts are to be appreciated in the light of a statutory provision, but, as a general rule, it does not relate to the question whether specific facts have occurred. 'There is no such thing as a specific margin within which a fact is or is not true and the administrative authority is free to choose. It should be possible to objectify fact-finding and the administrative authority and the court should arrive at the same assessment.' ${ }^{\text {I2 }}$ In addition, the courts' own responsibility to establish facts is advocated on the basis of arguments such as the persuasiveness of judicial decisions and the courts' authority. ${ }^{13}$

Counterarguments in favour of interpreting the administrative law courts' task as a limited one are advanced in academic literature as well. According to this line of reasoning, the courts' task is not to establish the facts themselves but to assess the lawfulness and care of the fact-finding process underlying the relevant decision. A court that assesses (new) evidence itself runs the risk of encroaching upon the administrative authority's law-creating power. If evidence was necessary to establish any right of the interested party or the administrative authority, the court cannot itself grant the relevant right on the basis of evidence acquired at a later date. ${ }^{\mathrm{I}}$ Further, it is pointed out that the administrative authority usually has more expertise for establishing facts. This argument is valid mainly where technical, medical, economic or a different kind of expertise is needed for finding facts. One could argue that in the case of complex facts of this kind, the administrative authority makes various normative and policy-based choices that must be respected by the court. Such normative and policy-based choices may lie in the assessment of the appropriate method of investigation of the facts, the admissibility and valuation of the alternative evidence and in the question whether the evidence gathered is sufficiently persuasive for the exercise of power. In that case, the courts should be permitted to review the administration's fact-finding only in terms of reasonableness. ${ }^{15}$ This limited test of reasonableness is also advocated for cases where it is inherently difficult to objectify the facts, as in asylum cases. If there is no 'hard' evidence but the administrative authority is prepared to establish a right in the event of a specific (un)certainty percentage, balancing of interests may be part of the fact-finding process. The courts should respect this policy assessment, which means that they cannot simply substitute their opinion on the facts

et al., De toekomst van de rechtsbescherming tegen de overheid, Den Haag: Boom Juridische uitgevers 2004, p. II2 et seq.

I2 Schuurmans (2005), p. 265-266.

I3 De Bock (200I), p. 45 .

I4 Daalder \& Schreuder-Vlasblom (2000), p. 2I4-22I and M. Schreuder-Vlasblom, Rechtsbescherming en bestuurlijke voorprocedure, Deventer: Kluwer 2006, p. I7I.

I5 M.A. Heldeweg, Normstelling en expertise. Waarborgen voor technische deskundigheid in het bijzonder bij vergunningverlening in het milieurecht, Den Haag: Sdu Juridische uitgevers I993, p. 298-302. Schuurmans (2005), par. 6.4. 
for the administration's opinion on the facts. ${ }^{16}$ Apart from these dogmatic aspects, more practical arguments play a role too. Court proceedings are less suitable for a detailed investigation into the facts than the decision-making process. The investigation of the facts could well jeopardise the requirement of dispute resolution within a reasonable period. ${ }^{17}$

The view that the courts should confine themselves to applying the test of reasonableness with respect to the administration's fact-finding makes heavy demands on the care and completeness of the investigation of the facts carried out by the administrative authority. According to this view, it is fitting to emphasize and accurately develop the requirements to be placed on the administration's fact-finding. This may include proper assistance to be provided by the administrative authority for the interested party in the context of the provision of proof; extensive possibilities for a debate on the facts in the adjudication process and strict requirements with respect to the statement of reasons underlying the decision. The case law of the Raad van State reveals - although not very consistently or accurately ${ }^{18}$ - such an emphasis on the duty of due care with respect to the administrative fact-finding procedure. ${ }^{19}$ Whether Dutch administrative law courts, the Raad van State included, in practice do apply a test of reasonableness when reviewing the facts is discussed in the next section.

\section{The Intensity of the Dutch Duty of Due Care Test}

It is difficult to analyse the intensity of the duty of due care test in actual cases on the basis of court decisions. Does scrunity of the care of the fact-finding procedure mean that the court no longer considers the accuracy of the fact-finding? Does the administrative authority have some latitude when it comes to establishing the facts? These questions are difficult to answer, because the court decision usually fails to provide an answer in explicit terms. The answer cannot usually be inferred implicitly either, because the statement of reasons underlying the court's opinion on the fact-finding is often quite limited. It is not exceptional if the court's decision solely states that 'the interested party failed to show that...'.

Nevertheless, there are a number of decisions in which the courts render an explicit opinion on the required intensity of review in relation to the facts. In such cases, the decision is usually the result of an explicit invocation of discretion in interpretation by the administrative authority or a reaction to the intensity of review applied by the first-instance court. The general rule apparent from these decisions is that the courts review the fact-finding in

i6 Schreuder-Vlasblom (2006), p. I72.

I7 Widdershoven (2005), p. 42.

I8 Barkhuysen, Damen et al. (2007), p. 328.

I9 Schuurmans (2005), chapters 4 and 5 . 
full and do not confine themselves to determining whether the administrative authority could have reasonably established the facts in the way it did. ${ }^{20}$ The courts make exceptions to this general rule, however. With respect to asylum law, the Raad van State has ruled that the courts may not substitute their own assessment of the facts for the administration's assessment. ${ }^{2 \mathrm{I}}$ In such cases, the courts must administer a limited test. If an administrative authority has established the facts according to a fixed evidence policy, the relevant case law shows that the courts hardly ever correct this fact-finding. Their test is usually confined to the question whether the evidence policy is supported by an objective statement of reasons. ${ }^{22}$ The arguments advocated in the literature for reviewing fact-finding in a limited way - expertise and a lack of 'hard' evidence ${ }^{23}$ - are sometimes recognised in the relevant case law.

These few decisions on intensity of review, however, do not reveal how the administrative law courts carry out their review in practice. The limited statement of reasons in court decisions forms an obstacle in ascertaining the intensity of review. Often it remains unclear what arguments and what means of proof the parties have advanced. Further, court decisions often lack the explicit weighing of arguments and means of proof by the court. As a result, the reader of a decision does not know how concretely the administration's fact-finding has been challenged and why the court disregarded the interested party's argument. In that case, it is impossible to determine how strictly the court reviews the administrative authority's fact-finding efforts. Empirical research has revealed some data. ${ }^{24}$ These courts of first instance render a negative opinion on the soundness of the fact-finding process in $28 \%$ of the cases where the administration's fact-finding is in dispute. The courts usually formulate their opinion on the facts in a cautious manner. They confine themselves to concluding that the administrative authority has investigated the facts insufficiently or has failed to state sufficient reasons for the decision, without being very precise about the kind of lack in the factual assessment. This means that in the case of a negative opinion, the courts allow the administrative authority room to arrive at the same factfinding in four out of five cases. Thus, the administrative law courts render a final opinion on the facts in very few cases indeed.

\footnotetext{
${ }^{20}$ Rechtbank Rotterdam (District Court Rotterdam) 20 September 2000, AB 200I, 93; Raad van State I5 July I996, AB I996, 4I4; Centrale Raad van Beroep 7 September 2000, TAR 2000, I47; Centrale Raad van Beroep (Central Appeals Tribunal) I4 November 2002, TAR 2003, 77; College van Beroep voor het bedrijfsleven I2 September 2006, JB 2006, 297.

${ }^{21}$ For example see Raad van State 27 January 2003, AB 2003, 286.

22 Schuurmans (2005), par. 5.2.2 and 6.4.4.

23 See the former section.

24 Barkhuysen, Damen et al. (2007), p. 290.
} 


\section{The National Administrative Law Courts and the Required Intensity of Review of the Facts Viewed from the EC Law Perspective}

In several Dutch publications, attention has been focused on the method of review adopted mainly by the Raad van State as viewed from the EC law perspective. ${ }^{25}$ The national court that assesses whether administrative decisions are in accordance with EC law may do so in a variety of manners. ${ }^{26}$ The Raad van State usually reviews these decisions on the basis of the principles of proper administrative procedure as well. In that case, the Raad van State itself does not assess whether the disputed decision is in accordance with EC law (specific review), but assesses whether in preparing the decision, the administrative authority has examined its conformity with EC law to a sufficient extent. If this examination is found to be insufficient, the decision is usually annulled because of a violation of the principle of due care and the duty to state reasons. If the court confines its work to this test, it hardly needs to investigate the facts itself. The question arises, however, whether this kind of formal test is consistent with the national court's duties as Community court. Does it offer private individuals sufficient legal protection, thus allowing them to effectuate their rights under EC law and does it check whether the administration has complied with EC law to a sufficient extent?

In specific cases EC law itself may define rules on evidence and factfinding by means of regulations and directives to be observed by the court hearing the action. ${ }^{27}$ The main rule, however, is that a Member State has procedural autonomy and may adopt its own procedures. National procedural law must, however, satisfy the well-known requirements of equality and effectiveness, as required by the Rewe doctrine. ${ }^{28}$ The question whether a duty of due care test with respect to fact-finding within the meaning of Article 3:2 of the GALA satisfies these requirements cannot be answered with absolute certainty. This issue has not yet been referred to the ECJ

25 Barkhuysen \& Damen et al. (2007), p. I39-I43; M.J. Jacobs \& W. den Ouden, 'De toetsing getoetst. De bestuursrechter en het EG-recht inzake staatssteun', in: W. den Ouden (ed.), Staatssteun en de Nederlandse rechter, Deventer: Kluwer 2005, p I-I8; J.H. Jans, Doorgeschoten? Enkele opmerkingen over de gevolgen van de Europeanisering van het bestuursrecht voor de grondslagen van de bestuursrechtspraak, Groningen: Europa Law Publishing 2005, p. 17-22; Widdershoven (2005) and R.J.G.M. Widdershoven, 'De Europese rol van de nationale rechter: rechtsbeschermer of controleur?', in: A.W. Heringa et al. (eds.), Het bestuursrecht beschermd: liber amicorum F.A.M. Stroink, Den Haag: Sdu uitgevers 2006, p. 57-69.

${ }^{26}$ J.H. Jans et al., Inleiding tot het Europees bestuursrecht, Nijmegen: Ars Aequi Libri 2002, p. I28-I35.

27 Barkhuysen, Damen et al. (2007), p. I28 et seq.

${ }^{28}$ Case 33/76 Rewe [I976] ECR I989. 
as a preliminary question. In Dutch literature the following answer can be found. In Europeanisation of Public Law, the Dutch authors reach the conclusion that the review of a decision on the basis of the principle of due care is not inconsistent with EC law. They infer from the Upjohn case to be discussed below that the ECJ allows the Member States much freedom and that any form of 'normal' review is to be regarded as permissible. ${ }^{29}$ Widdershoven endorses this conclusion elsewhere, albeit in more cautious terms..$^{\circ}$ In his opinion, the test against the principle of due care satisfies the requirements of equality and effectiveness, because in purely national administrative proceedings, the Raad van State frequently tests decisions against the principle of due care, which means that the equality requirement is satisfied. Nor does he believe that the effectiveness-principle has been violated. After the annulment on the basis of the principle of due care, the administrative authority must prepare and adopt a decision that does satisfy the relevant EC law standards. It is true that this may be more cumbersome than obtaining a definitive decision on the compliance with EC law, but one cannot say that the exercise of rights derived from EC law is rendered extremely difficult or impossible. Jans' application of the Rewe doctrine leads to a somewhat different result. He does not rule out that the equality principle is violated if the Raad van State systematically avoids the application of a substantive test against EC law. Decisions that are fully based on national law are sometimes tested substantively for compatibility with national rules of a higher rank. In the context of the principle of effectiveness, he observes that the test against the principle of due care is more unfavourable in terms of effective implementation of EC law than specific review. For this reason, he takes the view that the national court must administer a substantive test against European law as much as possible, but in doing so, he does not seem to conclude that there is a true legal duty. ${ }^{3}$ In general, it is assumed in Dutch literature that the administrative law courts may limit their EC law check to a test designed to ascertain whether the administrative authority has carefully examined whether the decision is consistent with EC law.

Incidentally, this 'cautious' conclusion is not drawn with respect to administrative law as a whole. In any case, state aid law requires a different approach. If an interested party asserts that a decision amounts to unlawful state aid, the test against the principle of due care would not satisfy the relevant requirement. This method of review is said to be inconsistent with the purpose and tenor of this part of EC law. To ensure compliance with the third paragraph of Article $88 \mathrm{EC}$, the national administrative law courts are required to establish whether the 'standstill' obligation has been violated. As

\footnotetext{
29 J.H. Jans et al., Europeanisation of Public Law, Groningen: Europa Law Publishing 2007 , p. 94 .

30 Widdershoven (2005).

3I Jans (2005), p. 2 I and 22.
} 
a general rule, they must then render a final opinion (also on the facts) on the question whether there is any unlawful state aid. ${ }^{22}$

Whether the Dutch standard of review of facts in competition cases is in accordance with EC law is hardly discussed. The College van Beroep voor het bedrijfsleven has tailored its method of review to the review applied by the Community courts, 33 as in cases like Tetra Laval, which will be discussed in section five.

The above views on the national courts' method of review are based to a great extent on the Upjohn case. ${ }^{34}$ This decision is of special interest to this contribution, because it deals with the question what test the national court must apply in reviewing the facts.

Upjohn took legal action against a decision to revoke all marketing authorisations relating to the drug Triazolam. It follows from Directive $65 / 65 /$ EEC that an authorisation of a medicinal product should be revoked where that product proves to be harmful. The potential harmful effect of Triazolam was discovered when a middle-aged woman killed her mother under the influence of the drug. In national proceedings, a discussion began about the question how the court should review the determination that the drug is harmful. The English Court of Appeal submitted a preliminary question on this issue. Upjohn argued that the directive and EC law in general require that the national court should be able to review the correctness of the decision, both with respect to the facts and the law, on the ground of a new and full assessment. On the other hand, the administrative authority asserted that it was the only national body competent to take decisions concerning the production and marketing of medicinal products and that the court could not substitute its opinion for that of the authority.

The ECJ does not endorse Upjohn's argument. The directive does not lay down detailed rules for the exercise of judicial review of revocation decisions. In that case, it is up to the Member State itself to organise the judicial review required, provided that the equality and effectiveness principles are complied with. The effectiveness principle does not require that the national court should be able to substitute its assessment of the facts, particularly scientific proof, for that of the administrative authority. The ECJ holds as follows:

' 33 As regards decisions revoking marketing authorisations taken by the competent national authorities following complex assessments in the medico-

32 P.C. Adriaanse, Handhaving van EG-recht in situaties van onrechtmatige staatssteun (PhD thesis Amsterdam, VU), Deventer: Kluwer 2006, p. 259-26I; Jacobs \& Den Ouden (2005), p. 7-8. See otherwise Widdershoven (2005), p. 50-54.

33 College van Beroep voor het bedrijfsleven 28 November 2006, AB 2007, 3I6 and Actualiteiten Mededingingsrecht 2007, p. 35-44. See L.E.J. Korstens \& M. van Wanroij, Nederlands mededingingsrecht, Deventer: Kluwer 2008, p. 222-224.

34 Case C-I20/97 Upjohn II [I999] ECR I-6927. 
pharmacological field, it does not appear that the only appropriate means of preventing the exercise of rights conferred by Community law from being rendered virtually impossible or excessively difficult would be a procedure for judicial review of national decisions revoking marketing authorisations, empowering the competent national courts and tribunals to substitute their assessment of the facts and, in particular, of the scientific evidence relied on in support of the revocation decision for the assessment made by the national authorities competent to revoke such authorisations.

34. According to the Court's case-law, where a Community authority is called upon, in the performance of its duties, to make complex assessments, it enjoys a wide measure of discretion, the exercise of which is subject to a limited judicial review in the course of which the Community judicature may not substitute its assessment of the facts for the assessment made by the authority concerned. Thus, in such cases, the Community judicature must restrict itself to examining the accuracy of the findings of fact and law made by the authority concerned and to verifying, in particular, that the action taken by that authority is not vitiated by a manifest error or a misuse of powers and that it did not clearly exceed the bounds of its discretion (see, in particular, Joined Cases 56/64 and 58/64 Consten and Grundig v Commission [1966] ECR 299, Case 55/75 Balkan-Import Export v Hauptzollamt Berlin-Packhof [1976] ECR 19, paragraph 8, Case 9/82 Øhrgaard and Delvaux v Commission [1983] ECR 2379, paragraph 14, Case C-225/91 Matra v Commission [1993] ECR I-3203, paragraphs 24 and 25, and Case C-157/96 National Farmers' Union and Others [1998] ECR I-2211, paragraph 39).'

With the Upjohn ruling, it was accepted that under certain circumstances a limited national judicial test of the fact-finding is sufficient. If the administrative authority has to make complex factual assessments the national court is not required to render its own opinion on the facts. This ruling answered a fairly specific question into the review of decisions adopted on the basis of a complicated fact-finding process in cases where the administrative authority had discretion. The ECJ issued some more instructions, however, about the national test required. It established a direct link with its own review in EC cases: 35

35 Cf. G. de Búrca \& Á. Ryall, 'The ECJ and Judicial Review of National Administrative Procedure in the field of EIA', in: Karl-Heinz Ladeur, The Europeanisation of Administrative Law. Transforming national decision-making procedures, Aldershot: Ashgate/Dartmouth 2002, p. I54 et seq.; Peter Oliver, 'The Standard of Review of Commission Merger Decisions: Life after "Tetra Laval”, in: Martin Johansson et al. (eds.), Liber amicorum in honour of Sven Norberg: A European for all seasons, Bruxelles: Bruylant 2006, p. 409 and 4I5; T. Tridimas, The General Principles of EU Law, Oxford: Oxford University Press 2006, p. 448 and 449; A. Ward, Judicial Review and the Rights of Private Parties in EC Law, Oxford: Oxford University Press 2000, p. 73 et seq. Peter Oliver explicitly suggests (p. 409) that the standard of review expressed in Upjohn is of the same nature as the standard of review in merger decisions, which will be discussed in the next section. 
' 35 Consequently, Community law does not require the Member States to establish a procedure for judicial review of national decisions revoking marketing authorisations, taken pursuant to Directive $65 / 65$ and in the exercise of complex assessments, which involves a more extensive review than that carried out by the Court in similar cases.'

Accordingly, the national court cannot be required to apply a method of review that is more intensive than the test applied by the Community courts. This means that the Community courts' own test has a normative function. Below, this fact will be addressed in greater detail. If we reach the conclusion that the Raad van State administers the same or a more intensive test than the one applied by the Community courts, we know that it will generally pass the EC law test. If the test administered by the Raad van State falls below this level, vigilance is required. In that case, the national court should take heed of the safeguards used by the Community courts in their review. ${ }^{36}$

\section{The Intensity of Review of Facts in Direct Appeal}

\section{I Introduction}

Below, the manner in which the Community courts review facts in direct appeals will be addressed. The preliminary reference procedure will be disregarded in this context, because in this procedure the Community court's task is somewhat different as far as the facts are concerned. In this procedure the national court is offered an explanation of substantive EC law in a case where the facts of the dispute have already been established by that national court. In that case, the Community court does not review the fact-finding by an administrative authority but renders a decision on the basis of the facts as established in the national judicial proceedings.

In the description of the review of facts in direct appeals, the CFI occupies an important position. As a general rule, the CFI now decides on direct appeals in the first instance. If subsequently an appeal is filed with the ECJ, the latter deals only with questions of law. ${ }^{37}$ Thus, the CFI has exclusive jurisdiction to find the facts and the ECJ does not render any opinion on the assessment and appraisal of facts, save where the clear sense of the evidence is distorted. $3^{8}$ Whether the CFI has imposed too high a standard of reason-

${ }^{36}$ Caranta (2008) describes the way in which the different legal traditions have influenced the concept of discretion of the Community courts.

37 Art. 225, para. I EC. See K.P.E. Lasok \& T. Millet, Judicial Control in the EU: procedures and principles, Richmond: Richmond Law \& Tax 2004, p. I88.

${ }^{8}$ Case C-390-95P Antillean Rice Mills and Others v. Commission [I999] ECR I-769, at para. 29; Case C-188/96P Commission v. V [1997] ECR I-656I at para. 24; Joined Cases C-204/00P, C205/00P, C-217/00P and C-219/00P Aalborg Portland A/S and Others v. Commission [2004] 
ing and standard of proof, whether it has applied the correct criteria in its appraisal of the facts and the evidence and whether it has applied the right intensity of review are all questions of law, though; the required standard of review arises from the law.

The ECJ and the CFI, which are required to ensure the correct application of EC law, have as their duty to review the facts. The lawful application of EC law can be ensured only if the law is applied with respect to accurate facts. This principle does not by definition result in an active court. No more than the Dutch administrative law courts will the Community courts initiate an investigation into the facts on their own initiative; it is primarily up to the parties to give satisfactory proof for their assertions. The assertion should be substantiated to a sufficient degree before the court starts an investigation into the facts. 39

The Community courts' activities have developed to a certain extent. When the ECJ still functioned as the sole court in the case of direct appeals, the investigation into the facts was limited. It hardly ever exercised its investigative powers..$^{\circ}$ The CFI is quite different in this respect. It engages in lengthy considerations concerning the findings of fact and frequently refers to information it received during hearings or from written questions. ${ }^{\text {I }}$ This cultural shift is intentional. One of the reasons for forming the CFI was the need for a more intensive review of the assessment of the facts, particularly in cases involving complex facts..$^{2}$ This need was fed by the Commission's overly strong institutional position. In the course of time, people began to level criticism at the Commission's position as 'police officer, prosecutor and judge' all in one, caused, inter alia, by the ECJ's restrained review of factfinding. ${ }^{43}$

The question how the court should deal with the administration's factfinding constitutes an explicit point of discussion also in proceedings following a direct appeal. Does the Community court have the right to substitute its own opinion on the facts for the Commission's opinion? Does it have the right to value all relevant evidence itself? Does the Community court also

ECR I-I23 at para. 47 to 50; Case C-403/04P Sumitomo Metal Industries v. Commission [2007] ECR I-729, at para. 38 to 40.

39 Mark Brealey, 'The Burden of Proof before the European Court', ELRev. I985, vol. IO, p. 250253; Lasok \& Millet (2004), p. 232 and 247; K. Lenaerts, D. Arts \& I. Maselis, Procedural Law of the European Union, London: Sweet \& Maxwell 2006, p. 557; G. Ress, 'Fact-finding at the European Court of Justice', in: R.B. Lillich (ed.), Fact-finding before International Tribunals, New York: Transnational Publishers i992, p. I83.

40 Ress (I992), p. I83. He describes the outcome of a study conducted in I982: in almost 30 years after the ECJ came into existence, it had heard only I20 witnesses in 28 cases and had appointed only II experts in 8 cases.

$4^{\mathrm{I}}$ See for example the cases of Pfizer and Tetra Laval to be discussed below.

$4^{2}$ Lenaerts, Arts \& Maselis (2006), p. I5.

43 See, among others, Ress (I992), p. I92 for this criticism. 
review on the basis of a duty of due care standard and, if so, how is this standard applied? The beginning of an answer will be given below. ${ }^{44}$ Naturally, the specific rules of evidence and the intensity of review for each substantive branch of law may vary. 45 The nature of these differences is primarily a question of European substantive law, which will not be addressed in this contribution.

\subsection{The Standard of Review of Facts}

It is undisputed that statutory interpretation is the domain of the court. The Community courts provide the ultimate interpretation of Community law. It is more difficult to answer the question whose domain the assessment of facts is. Fact-finding will invariably be part of the administration's decision-making. As far as public-law procedures are concerned, the court nearly always refrains from repeating the fact-finding process but, instead, reviews the fact-finding procedure. ${ }^{46}$ If the correctness of the facts is in dispute, it is in general acknowledged that the judge should apply a full review. 'Either a fact is correct or it is not.'47 Things get complicated however when the review of a factual appreciation is in dispute, which may be part of a discretionary power. A limited review of the administration's factual appreciation may then be appropriate. Sometimes it is even hardly possible to make a clear distinction between fact and appreciation. For example, the quantification of particular primary facts may inevitable be the result of an intellectual construction. ${ }^{4}$

Above, it was already stated that the ECJ was not very active in scrutinizing the fact-finding process. It nearly always exercised 'judicial selfrestraint'. 49 In a contribution from I992, Ress described this restraint in relation to the action for annulment and to anti-dumping cases. He explains the restrained review of the facts partly on the basis of treaty provisions, ${ }^{50}$ partly on the basis of the doctrine of the separation of powers and partly on the basis of the excessive workload of the ECJ. In the end, the degree of intensity of the review of facts is determined by the complexity of the facts at issue:

\footnotetext{
44 In this respect I have benefited greatly from Paul Craig, EU Administrative Law, Oxford: Oxford University Press 2006, Chapter I3: 'Law, Fact and Discretion', p. 429-48I.

45 Cf. De Búrca \& Ryall (2002), p. I59.

${ }^{46}$ Cf. D. Baily, 'Scope of Judicial Review under Article 8I EC', [2004] CMLRev. , p. I330.

47 Bo Vesterdorf, 'Standard of Proof in Merger Cases: Reflections in the Light of Recent Case Law of the Community Courts', [2005] European Competition Journal, p. I5.

$4^{8}$ Cf. Hubert Legal, 'Standards of Proof and Standards of Judicial Review in EU Competition Law', [2006] Annual Proceedings of the Fordham Corporate Law Institute (vol. 32), p. II4.

49 Ress (1992), p. 187.

50 Especially Article 33 ECSC.
} 
'The more complex the underlying facts are, the more difficult it is to label a decision objectively wrong, i.e., just review a decision judicially instead of overtaking the role as decisionmaker, a role which belongs to the executive branch.'51

'Whenever the borderline between facts and law becomes unclear, the court withdraws and leaves the facts as far as possible to other institutions.'52

Accordingly, the ECJ generally exercised restraint in reviewing the Commission's assessment of the facts. In specific cases, it even recognised the test of reasonableness. In some policy areas, the Community institution has wide discretionary power, for example, in the field of agricultural policy or in the field of protective measures and commercial policy. This discretionary power need not be limited to the interpretation of factual standards and policy choices in relation to, for example, the objectives to be pursued or the means that are considered suitable. If the Community institution is to make a complicated assessment on facts, the administrative authority's discretion also relates to a certain extent to fact-finding. In this respect the ECJ uses terms like discretion in relation to 'findings of the basic facts' or the 'establishment of the factual basis of the action'.

'When the implementation by the Council of the agricultural policy of the Community involves the need to evaluate a complex economic situation, the discretion which it has does not apply exclusively to the nature and scope of the measures to be taken but also to some extent tot the findings of the basic facts inasmuch as, in particular, it is open to the Council to rely if necessary on general findings. In reviewing the exercise of such a power the court must confine itself to examining whether it contains a manifest error or constitutes a misuse of power or whether the authority in question did not clearly exceed the bounds of its discretion. ${ }^{53}$

An assessment of the facts is complex, for example, where complicated economic or social assessments must be made, or where an assessment is otherwise based on specific scientific data. Under what circumstances, for example, is there a case of 'state aid' or a 'serious public health risk'? The Community courts may not substitute their own assessment of the facts for the Community institution's assessment in the case of complex facts. EC law

51 Ress (I992), p. I87.

52 Ress (1992), p. I91.

53 Case C-I38/79 Roquette frères v. Council [I980] ECR 3333, at para. 25. Cf. Case C-I97/80200/80 Ludwigshafener Walzmühle a.o. v. Council and Commission [I98I] ECR 32II, at para. 37; Case C-27/95 Bakers of Nalisea [I997] ECR I-I847, at para. 32, Case C-4/96 NIFPO and Northern Ireland Fishermen's Federation v. Department of Agriculture for Northern Ireland [I998] ECR I-68I, at para. 4I and 42; Case T-I3/99 Pfizer Animal Health v. Council [2002] ECR II-I96I, at para. I68. 
has assigned this task to the administration. Craig describes this 'old' line in EC case law. He is of the opinion that it is not the treaty text that forms an obstacle to more intensive review, but explains this restraint primarily by referring to efficiency considerations. He argues that intensive review of fact-finding is time-consuming and may induce parties 'to second-guess evaluations'. In addition, the ECJ was the only court that was able to check the validity of the acts performed by the Community institutions, as a result of which overburdening of the ECJ was a real danger.54

If we compare the above line with the Dutch case law of the Raad van State and with the view taken by the advocates of limited judicial review, 55 we can observe clear parallels. The judicial task of rendering a final opinion on complex facts does not fit into the system of the separation of powers. Policy aspects may be part of the fact-finding process and the administration is responsible for these assessments. And in the Dutch national system, too, attention is paid to procedural efficiency and the risk of overburdening the court. Yet, there is a clear difference. The explicit recognition that administrative discretion may extend to 'findings of the basic facts' cannot, apart from cases in asylum law, be found in the Dutch case law, as opposed to EC law.

After the description of this 'old' line, Craig shows on the basis of a thorough case law analysis that the test of reasonableness with respect to facts became more intensive in the course of time. ${ }^{6}$ He argues that this development was most apparent in competition law cases under the guidance of the CFI, but he also perceives this tendency in the case law relating to common policies, state aid and structural funds. ${ }^{77}$ 'It is clear that while retaining the established grounds of review the Community courts, and more especially the CFI, have been applying these with greater intensity than hitherto.

This is, as will be seen later in the discussion, a common phenomenon in national legal systems. ${ }^{5}{ }^{8}$ Biondi and Harmer describe an increased intensity of review exercised over Community measures in environmental law and an increased attention for scientific evidence. 59 The Community courts still use the same words for defining their restrained review: manifest error, abuse of power, and manifestly excessive use of administrative powers. Even so, the

54 Craig (2006), p. 439-446.

55 See section 2 and 3.

${ }^{6}$ Craig (2006), p. 446-464. Cf. Rostane Mehdi, 'La preuve devant les juridictions communautaires', in: Hélène Ruiz Fabri \& Jean-Marc Sorel (eds.), La preuve devant les juridictions internationals, Paris: Pedone 2007, p. I76-I8I and the commentary of Hubert Legal, p. I86I87.

57 Craig (2006), p. 457-462.

58 Craig (2006), p. 446.

59 Andrea Biondi \& Katherine Hamer, 'Scientific Evidence and the European Judiciary', in: A. Biondi et al. (eds.), Scientific Evidence in European Environmental Rule-making, The Hague: Kluwer Law International 2003 , par. 2.I. 
intensity of the test seems to have increased, because the courts are more readily prepared to accept a 'manifest error'.

It would be beyond the scope of this contribution to deal with the wide variety of case law discussed by Craig in detail. After a study of a portion of this case law, I will pinpoint some aspects of the manner in which the Community courts review the factual assessments, 'even' where this test is of a restrained nature. Two cases, to wit Pfizer and Tetra Laval, demonstrate the potential degree of detail of a test of reasonableness. The following discussion of the relevant case law does not pretend to give a general picture of the Community courts' review of the facts. ${ }^{60}$ This description is meant to show that the relevant EC case law includes elements that may be used to give substance to a national 'duty of due care or duty to state reasons test' in relation to fact-finding. These review aspects may well be a source of inspiration for the Dutch administrative law courts where these test the administration's fact-finding against Article 3:2 of the GALA. In addition, the case law shows that intensive review of the fact-finding procedure and review whether the facts established are in accordance with the truth need not be diametrically opposed to each other as review concepts, which is regularly done in Dutch academic literature.

\subsection{The Cases of Pfizer and Tetra Laval: An Operation of the Standard of Review of Facts}

In the Pfizer case, the CFI pays detailed attention to the review of the assessment of the facts. ${ }^{6 \text { I }}$ Pfizer instituted legal proceedings in connection with the adoption of a regulation under which a specific antibiotic was prohibited as an additive in animal feeds. The measure was taken for fear of the risk that specific drugs could become ineffective for human use as a result of the use of a specific antibiotic (virigniamycin). The parties agree that there was no scientific proof for the development for such resistance at the time of the adoption of the regulation. Nevertheless, the Council took the disputed measure on the basis of the precautionary principle. The relevant EC case law shows that this kind of preventive measure cannot be based on a purely hypothetical approach to the risk. The risk of transfer and resistance, although the reality and extent thereof cannot be fully demonstrated by conclusive scientific evidence, should be supported by sufficient scientific data. ${ }^{62}$ The CFI divides its own factual test of the public health risk into two stages: first, it reviews whether the findings of fact were correct and subsequently it reviews whether the appreciation of the facts exceeded the

\footnotetext{
${ }^{60}$ Though this jurisprudence does illustrate that the judicial review of facts has been intensified.

6r Case T-13/99 Pfizer Animal Health SA v. Council [2002] ECR II-3305.

${ }^{62}$ Pfizer, at para. I43 and I44.
} 
bounds of discretion. ${ }^{63}$ The Community institution has these two tasks in assessing health risks as well. The CFI states that political considerations may play a role only in respect of the appreciation of the facts, e.g. the question of the risk level that is deemed acceptable. ${ }^{64}$

Accordingly, the CFI states explicitly what test it must administer itself. For the Dutch situation this is of interest, because the Raad van State hardly does this explicitly. Because the Community institution must make a complicated assessment, its discretion extends to a certain degree to the factual basis of its action. The CFI will then administer the above-mentioned test of reasonableness, emphasizing that if it is difficult to establish facts objectively, the procedural guarantees are of even greater importance (for more details, see section six). Those guarantees include, in particular, the duty of the competent institution to examine carefully and impartially all the relevant aspects of the individual case. A fact-finding based on scientific information should be founded on principles like 'excellence, transparency and independence'. These important procedural guarantees must ensure the scientific objectivity. ${ }^{65}$ The CFI by no means confines itself to the conclusion that the Community institution has discretion in interpretation and that insufficient proof has been submitted that its opinion was manifestly erroneous. Despite the limited nature of the test, the CFI specifies the elements of its test in more detail. The requirements arising from the principles of 'excellence, transparency and independency' that the administration should satisfy are defined in concrete terms. For example, the CFI examines to what extent the Community institution is bound to seek expert advice and what responsibilities have been entrusted to the Community institution. (For example, the Community institution must prepare the factual questions which the experts need to answer. Furthermore it has to asses the probative value of the report, in which context it must examine whether the reasoning of the advice is full, consistent and relevant. The administration may deviate from the advice or use only part thereof, as it is responsible for the exercise of public authority. The advisory body cannot take over this responsibility, because it bears only scientific and no political responsibility.) ${ }^{66}$ Further, the CFI specifies what requirements should be placed on the statement of reasons underlying the decision if the administration decides to deviate from the advice. (The Community institution must provide specific reasons that are geared towards the assessment included in the advice and that should be of at least the same scientific level as the advice itself. The reasons should be based on an appropriate, accurate and impartial analysis of all the relevant aspects of the individual case, which include the reasoning on which the

\footnotetext{
63 Pfizer, at para. I28.

64 Pfizer, at para. I50.

${ }_{65}$ Pfizer, at para. I72.

66 Pfizer, at para. I98 and 20 I.
} 
advisory body based the findings in its opinion. $)^{67}$ The CFI also specifies what body is to be regarded as an expert body and what legitimizes this body. (For example, the scientific committee's opinion cannot be replaced by an opinion of the permanent committee, because - despite the members' professional ability - it must be considered a political body representing the Member States that is not independent. $)^{68}$

After it has drawn the conclusion that the Community institution did not make any errors in establishing the relevant facts, the CFI assesses whether the institution could reasonably have rendered the opinion that the antibiotic constitutes a public health risk. The CFI accurately ascertains what conclusions can be based or cannot be based on the relevant expert advice, on the basis of the arguments put forward. However, it will not deal with the substantive accuracy of this scientific advice. This is the core of the test of reasonableness administered by the $\mathrm{CFI}$ :

'It is not for the Court to assess the merits of either of the scientific points of view argued before it and to substitute its assessment for that of the Community institutions, on which the Treaty confers sole responsibility in that regard. In the light of the foregoing, the Court nevertheless finds that the parties' arguments, supported in each case by the opinions of eminent scientists, show that there was great uncertainty, at the time of adoption of the contested regulation, about the link between the use of virginiamycin as an additive in feedingstuffs and the development of streptogramin resistance in humans. Since the Community institutions could reasonably take the view that they had a proper scientific basis for a possible link, the mere fact that there were scientific indications to the contrary does not establish that they exceeded the bounds of their discretion in finding that there was a risk to human health.' ${ }^{69}$

Despite the limited review, the CFI devotes more than 200 paragraphs to the standard of review and the review of the Community institution's opinion on the facts.

The much discussed case of Tetra Laval70 illustrates the more intensive review in competition law. This case merits special attention, because a complaint was lodged with the ECJ on the method of review applied by the CFI, claiming that this was too intensive. ${ }^{7 \mathrm{I}}$

67 Pfizer, at para. I99 and 203.

68 Pfizer, at para. 280 to 287.

69 Pfizer, at para. 393.

70 Case T-5/O2 Tetra Laval BV v. Commission [2002] ECR II-438I.

7I Case C-I2/03P Commission v. Tetra Laval BV [2005] ECR I-987; Pending Case C-4I3/o6P Bertelsmann and Sony Corporation of America v. Impala in this context is definitively worth mentioning. The appellants are of the view that the CFI misinterpreted the standard of reasoning and the standard of proof and exceeded its scope of judicial review by substantiating its own assessment of the facts and of the evidence for that of the Commission. 
The Commission declared the reported concentration Tetra Laval/Sidel incompatible with the common market. This new entity would obtain a dominant position in the PET market (polyethylene terephtalate, used for manufacturing plastic packaging) by using its existing dominant position in the carton sector as a lever. The decision was annulled, because the Commission had provided insufficient proof for its conclusion that the potential leveraging would lead to the creation or strengthening of a dominant position on the relevant markets. There was insufficient proof for the various findings of fact. Further, the Commission was criticized for having failed to conduct an accurate investigation. The CFI found that the Commission had conducted a one-sided investigation as it had considered only factors indicative of anti-competitive conduct and had ignored factors indicative of the opposite. The Commission was also criticised for having overestimated the likely level of growth of the PET sector.

On appeal, the Commission argued that the CFI pays lip service to the test of manifest error of assessment, but that essentially, it substitutes its own opinion on the facts for the Commission's opinion. The Commission argued that in requiring the Commission to submit convincing proof, the CFI administers too intensive a test. The ECJ declared this appeal unfounded: the CFI had applied a proper standard of review. Also in administering a test of reasonableness, a court must consider whether the evidence is factually accurate, reliable and consistent and whether all relevant information has been gathered.

'Whilst the Court recognises that the Commission has a margin of discretion with regard to economic matters, that does not mean that the Community Courts must refrain from reviewing the Commission's interpretation of information of an economic nature. Not only must the Community Courts, inter alia, establish whether the evidence relied on is factually accurate, reliable and consistent but also whether that evidence contains all the information which must be taken into account in order to assess a complex situation and whether it is capable of substantiating the conclusions drawn from it. Such a review is all the more necessary in the case of a prospective analysis required when examining a planned merger with conglomerate effect..$^{2}$

By requiring accurate and convincing evidence, the CFI did not enhance the intensity of its review, according to the ECJ. Such requirements with respect to evidence relate to the core function of evidence, 'which is to establish convincingly the merits of an argument or, as in the present case, of a decision on a merger'.73 Particularly high requirements of care are placed on the prospective analysis, all the more because this analysis concerns potential future events rather than past events for which often numerous data are

72 Commission v. Tetra Laval BV, at para. 39.

73 Commission v. Tetra Laval BV, at para. 4I. 
available. According to the ECJ, the extent to which the prospective analysis is realistic can be determined only if this analysis is based on sound evidence. ${ }^{74}$ The CFI administered the proper judicial test. 'It explained and set out the reasons why the Commission's conclusions seemed to it to be inaccurate in that they were based on insufficient, incomplete, insignificant and inconsistent evidence.'75 For example, the CFI had established that only one of the three independent reports cited by the Commission contained relevant information on the use of PET packaging for milk. Further, it established that the market growth predicted in the report is rather insignificant. In addition, the CFI found that one of the Commission's conclusions concerning the facts was inconsistent with undisputed data in other reports and that a specific analysis was incomplete, which made it impossible to confirm its forecast..$^{6}$

Naturally, Pfizer and Tetra Laval are only two - remarkable - cases and do not necessarily represent the Community review in general. Nevertheless, they are worth examining from a national administrative law perspective, because they include the court's specification of how it reviews an opinion on the facts by the administration. Moreover, decisions in cases like Tetra Laval appear to be formulated in such a manner that they may be used as a guideline for future cases. ${ }^{77}$ That the importance thereof should not be underestimated is also underlined by Bo Vesterdorf, former President of the CFI, when he discusses the manner of review in some competition cases. He personally thinks that the CFI has not changed its review but it has only defined its review in more precise terms. The manifest error test does not result in a detached review of the opinion on the facts. The court accurately examines whether an opinion on the facts can be based on the evidence gathered. The test of reasonableness does mean that the administration's characterization of the facts is endorsed as a general rule if no or only small errors have been made in the fact-finding process:

'I would reject the charge that the CFI had adopted a new approach to reviewing substantive Commission MCR [Merger Control Regulation] decisions. ${ }^{78}$

74 Between the establishment of primary facts as well as the direct factual inferences drawn therefrom and the appreciation of the prospective economic analysis a clear distinction is made. Legal (2006), p. IIO-III; Bo Vesterdorf, 'Certain Reflections on Recent Judgments Reviewing Commission Merger Control Decisions', in: M. Hoskins \& W. Robinson (eds.), A True European: Essays for Judge David Edward, Oxford: Hart 2003, p. I36-144 and Vesterdorf (2005). In this publication of 2005 Vesterdorf also underlines the theoretical distinction between the standard of proof, which is primarily directed to the administration, and the standard of judicial review.

75 Commission v. Tetra Laval BV, at para. 48.

${ }^{76}$ Commission v. Tetra Laval BV, at para. 46.

77 J. Schwarze, European Administrative Law, London: Sweet \& Maxwell 2006, p. clii.

$7^{8}$ Vesterdorf (2003), p. I37. 
'[...] the CFI has simply been more exacting latterly than it arguably was previously when applying the well-established principles to which I have referred. It has also, I believe rightly, required convincing proof for findings based on novel or contested economic theories. This follows, it must be recalled, considerable adverse academic analysis, as well as persistent criticism from practitioners [...] of the Commission's perceived unparalleled role as investigator, prosecutor and judge in such cases. [...]

Consequently, if the Commission presents a case for or against a merger [...] in a contested decision in which, for example, it has clearly overlooked, underestimated or exaggerated the relevant economic data, drawn unconvincing, in the sense of implausible, direct inferences from primary material facts or adopted an erroneous approach to assessing the material facts, such failings may, depending on their cumulative effect in the context of the circumstances of the case viewed as a whole, suffice to constitute [...] a manifest error of assessment. On the other hand, if no such (or very few or insignificant such) errors are found, then the CFI, even if it would not itself have subscribed the Commission's economic assessment of the foreseeable effects of the merger and/or the adequacy of the commitments offered, should uphold the Commission's findings.'79

\subsection{Lessons to Dutch Administrative Law Courts}

In the discussed case law, the administration's task and the court's task in the fact-finding process are distinguished, but - contrary to what is customary in Dutch legal literature - not sharply contrasted. The court does not establish the facts all over, but this does not mean that its review is restrained. The court requires proper substantiation of the assessment of the facts in the decision and it assesses whether the evidence the administration has gathered has resulted in a sufficient degree of certainty. If the fact-finding process is reviewed intensively, the court also reviews to a great extent whether the facts established are accurate.

More attention for the review of facts in a Community context could improve the testing of a duty of due care and duty to state reasons as applied in the Netherlands. I believe that there is need for this, considering the lack of clarity about the nature and intensity of this test in our national courts. The case law of the Dutch administrative law courts could specify that the courts are competent (and even obliged if the facts are disputed) to review whether the evidence is accurate, reliable and consistent, whether the administrative authority has gathered all relevant information and whether the evidence is convincing. If the administration has used expert information, the principles of 'excellence, transparency and independence' derived from EC case law could reveal a more specific review of the expert opinion. This does not mean that the Dutch administrative law courts do not apply such

79 Versterdorf (2003), p. I43. 
requirements at present. It is difficult to determine precisely the manner of review they do apply. ${ }^{80}$ The explicit specification of the above requirements could solve this problem to a great extent. Moreover, for the sake of clarity, it is important not to confuse the concept of the test of reasonableness with the concept of reviewing the facts in a detached way. The courts should accurately examine what conclusions are based on the evidence and whether the administration has gathered all relevant information. The limited nature of the test of reasonableness does not detract from the requirements with respect to the allocation of the burden of proof, the standard of proof and assessment of the evidence. ${ }^{81}$

\section{Community Review of Facts and the Principle of Due Care}

In the previous section, it was pointed out that the Community courts review fact-finding conscientiously, even though they assess the appreciation of the facts only by administering the test of reasonableness. This case law defines standards on the basis of which the courts may carry out their review. In addition to the emphasis put on the elements the courts assess, attention is also paid to the stage of preparation of the decision against which the appeal was filed. In this respect there is a clear parallel with Dutch administrative law. In reviewing the correctness of the facts, and particularly where it is difficult to establish the facts objectively, part of the judicial review concentrates on the standards to be heeded by the administration in its decision-making. The question whether the administration has taken heed of the principle of due care and the duty to state reasons, may become the main issue. EC case law also applies these requirements. ${ }^{82}$ This duty to state reasons is an essential procedural requirement and finds expression in Article 253 EC and Article 4I(2) of the Charter of Fundamental Rights of the European Union. The strong link established by the CFI and the ECJ between procedural requirements and the test of reasonableness with respect to factual assessments is remarkable in this context. Since Technische Universität München, it has been established case law that the courts should emphasize procedural requirements if a Community institution exercises a discretionary power:

80 The obligation to justify judicial decisions, especially in the free evaluation of evidence, is stressed by Jordi Ferrer Beltrán, 'Right to Proof and Rationality of Judicial Decisions', in: Jordi Ferrer Beltrán \& Maribel Narváez Mora, Law, Politics, and Morality: European Perspectives II, Berlin: Duncker \& Humblot 2006, p. I75-I90.

8I Craig (2006), p. 466; Vesterdorf (2005).

${ }^{82}$ X. Groussot, General Principles of Community Law, Groningen: Europa Law Publishing 2006, p. 253-257; Tridimas (2006), p. 406 et seq. In pending Case C-4I3/o6P Bertelsmann and Sony Corporation of America v. Impala the extent of these principles form the main question when the Commission's assessment of the facts is in dispute. 
'However, where the Community institutions have such a power of appraisal, respect for the rights guaranteed by the Community legal order in administrative procedures is of even more fundamental importance. Those guarantees include, in particular, the duty of the competent institution to examine carefully and impartially all the relevant aspects of the individual case, the right of the person concerned to make his views known and to have an adequately reasoned decision. Only in this way can the Court verify whether the factual and legal elements upon which the exercise of the power of appraisal depends were present.' ${ }^{83}$

The administration's discretionary power is counterbalanced by a strict check on the extent to which procedural safeguards have been heeded. ${ }^{84}$ By virtue of the principle of due care and the duty to state reasons, the courts may require the administration to take account of all relevant circumstances and to investigate all elements of the file carefully; that it arranges sufficient expertise within its own organisation or engages an expert committee; that it recognizes the inconsistency of information and examines it in more detail; that it indicates explicitly that a request has been dismissed because of the absence of means of proof. ${ }^{85}$ By emphasizing the principle of due care and the principle to state reasons, the Community courts succeed in receiving the information they need for exercising their judicial check. ${ }^{86}$ In fact, these principles constitute the preliminary stage necessary for achieving the judicial review of facts as described in the previous section. By setting clear and strict requirements on the administration's investigation of the facts and the statement of reasons underlying the factual assessment, the Community courts are able to guarantee that their test of reasonableness actually provides legal protection. For example, it is possible to determine whether the Community institution has drawn logical conclusions from the evidence only if the decision is sufficiently supported by reasons. Procedural rights are utilized in order to achieve a proper substantive result of the matter. The Community courts then have sufficient material at their disposal to assess

83 Case C-269/90 Technische Universität München v. Hauptzollamt München-Mitte [I99I] ECR I-5469, at para. I4.

${ }^{84}$ Cf. K. Lenaerts, 'Some Thoughts on Evidence and Procedure in European Community Competition Law', Fordham International Law Journal 2007, p. I48I and I482.

85 See, besides Technische Universität München and Pfizer, at para. I7I by way of example: Case T-6I3/97 Ufex a.o. v. Commission [2000] ECR II-4055, at para. 65 et seq.; Case T-24I/00 Le Canne v. Commission [2002] ECR II-I25I, at para. 53 et seq.; Case T-285/03 Agraz a.o. v. Commission [2005] ECR II-Io63, at para. 49 et seq.; Case T-4I3/03 Shandong Reipu Biochemicals v. Council [2006] ECR II-2243, at para. 63 et seq.; Case T-228/02 Organisation des Modjahedines du peuple d'Iran v. Council [2006] ECR II-4665, at para. I59.

${ }^{86}$ Cf. Craig (2006), p. 479-48I; J. Schwarze, 'Judicial Review of European Administrative Procedure', [2004] Law and Contemporary Problems, vol. 68, p. 94-96; Schwarze (2006), p. cli. 
whether the evidence is factually correct, reliable and consistent and whether the administrative authority has collected all relevant information. There is a specific interaction between the emphasis on procedural requirements and more intensive judicial review of fact-finding. 'Between law and fact, the ECJ clearly puts consistency and relevance of the reasoning and sufficiency of the documentation on the side of facts because it is necessary that they be reviewed if there is any will to have an effective review conducted. ${ }^{187}$ This case law illustrates that the distinction between review based on procedural requirements and review based on substantive legal grounds may be of minor significance. ${ }^{88}$

As described in the first three sections, the principle of due care, combined with the duty to state reasons, constitutes an important fact-finding standard in Dutch administrative law as well. The principle constitutes both a standard for the administration's conduct and a criterion for the court to review the assessment of the facts. In Dutch administrative law, too, the general principles of proper administration have been developed for the purpose of shaping the lawfulness check of the exercise of discretionary powers in particular. ${ }^{89}$ One of the differences, however, is that Dutch case law does not dictate that these principles should be checked very strictly where there is administrative discretion. Of course, it is fair to assume that the court will rely on the principles in the case of discretion, but the requirements arising from the principles are not worked out in great detail and explicitly emphasized. To the contrary, there seems to be reluctance to increase the duty to state reasons, as it may constitute a vehicle for the judiciary to substitute its own opinion for that of the administration. $9^{\circ}$ Another difference is that the Community courts do not simply define their review of facts by testing against the principle of due care and the duty to state reasons and that they formulate further requirements for the administration. Apart from these principles, they explicitly define elements on the basis of which they should carry out their own lawfulness check.

\footnotetext{
${ }^{87}$ Legal (2006), p. II4.

88 Cf. Craig (2006), p. 479 and Tridimas (2006), p. 408. Tridimas points out that by entrenching process rights the ECJ finds an answer to the problem of a melting pot of national legal cultures, in which the degree of substantive scrutiny varies.

${ }^{89}$ Van Wijk/Konijnenbelt \& Van Male, Hoofdstukken van bestuursrecht, Den Haag: Elsevier 2005, p. 276.

$9 \circ$ Annual report of the Raad van State 2006, p. Ioo. See, for example, Raad van State I5 June 2006, AB 2006, 295, at para. 2.6.6.
} 


\section{Conclusion and Final Observations}

If in actions before the national courts EC law is involved, EC law does not directly provide for the manner in which and the extent to which the national courts should review the fact-finding underlying a decision. The manner of review is part of the Member States' procedural autonomy, though its procedural law must satisfy the requirements of equality and effectiveness. Review elements can be derived from EC law, which may also be normative to the national courts. In Upjohn, the ECJ indicated that the national courts cannot be expected to review facts more intensively than the ECJ itself does in similar cases. Accordingly, the Community test has a normative effect to a certain degree. A major part of this contribution deals with the nature of the Community review of fact-finding in direct appeals. The selection and emphasis of certain topics has been inspired by the debate on the proper review of facts in Dutch administrative law.

EC law also addresses the question whether the administration or the courts are responsible for the correctness of the assessment of the facts. The courts must verify whether the relevant decision is based on accurate facts, but it is not their task to establish the facts once more. This is almost inherent to administrative law procedures. EC law recognizes that the administration's discretion in interpretation may include fact-finding to a certain extent as well. This situation occurs when the facts are complex, for example, in difficult economic analyses. In that case, the Community courts review the administration's opinion on the facts by administering the test of reasonableness and consider whether there is a manifest error, abuse of power or the excessive use of power. In the course of time, this review has been intensified. Despite the administration's discretionary power, the CFI closely examines whether the evidence on which the decision is based is factually accurate, reliable and consistent, whether the administrative authority has gathered all relevant information and whether the evidence is convincing. This explicit specification of the lawfulness check could be useful in Dutch administrative law as well. Dutch administrative law courts do review the administration's fact-finding against the principle of due care and the principle to state reasons, but the specific elements included in the courts' review of facts often remain invisible. The reasoning on whether the administration's assessment of the facts can pass the review test is in general very limited. In addition, the Dutch administrative law courts' attention is focused mainly on the requirements to be imposed on the administrative authority in the context of fact-finding. EC case law also provides an insight into the manner in which and the elements on the basis of which the courts subsequently review this fact-finding. Moreover, EC law provides more clarity on the meaning of the test of reasonableness in terms of the assessment of facts. A test of reasonableness does not restrict the courts' task of closely examining the reliability of the evidence. Nor does the test of reasonableness prevent the courts from having the last word on the rules 
of allocation of the burden of proof, standard of proof and assessment of evidence. These subjects are part of the courts' domain. The test of reasonableness does prevent the courts from substituting their own opinion on the facts for the administration's opinion on the facts. Whenever the factual and evidential position may lead two reasonable persons to different assessments, the margin of appreciation ought to be left to the administration. If the fact-finding is based on reliable evidence, the courts will not easily arrive at a different assessment of the facts.

The ECJ and the CFI also apply procedural principles in their review of a Community institution's factual assessment. They consider the procedural safeguards, including the principle of due care and the duty to state reasons, to be of more fundamental importance if a discretionary power is exercised. The emphasis on these procedural principles is used for the benefit of the judicial review. As a result of the strict requirements with respect to the investigation of the facts and the statement of reasons underlying the administration's opinion on the facts, the courts have the instruments to check the accuracy of that opinion.

If we ultimately compare the method of review applied by the Community courts to that of the Dutch Raad van State, both similarities and differences stand out. All in all, the Raad van State is not in an exceptional position when it reviews the decision mainly against formal principles and refrains from establishing the facts definitively. The Community courts also assess whether a Community institution could have arrived at a specific assessment of the facts. If they perceive defects in the fact-finding process, they will not establish the facts themselves. This is the administration's responsibility. And as in national law, the principle of due care and the duty to state reasons are standards on the basis of which the fact-finding may be reviewed. But there are differences as well. The recognition that the administration's discretion may also extend to fact-finding ('basic data') means that the Community courts apply the test of reasonableness - at least explicitly - with respect to fact-finding more frequently than the Raad van State. This conclusion does not mean, however, that the position of an interested party disputing the facts is less advantageous before the Community courts than before the Dutch administrative law courts. The former specify the lawfulness check to be applied much more precisely than the Raad van State does. In general, the Community courts indicate in more concrete terms against what standards the review is applied. In individual cases, they also indicate more clearly the concrete defects attached to the fact-finding. Even though the courts do not establish the facts themselves, the parties can understand the points where the factual assessment has failed to pass the test of criticism. Though the Community courts do not assess the facts definitively, their decisions further the resolution of the dispute to a greater extent. The explicit specification of the review standard in EC case law could help to give further substance to the judicial review of fact-finding in Dutch administrative law. 
Of course, the question arises whether the Raad van State is obliged to amend its review on the basis of EC law. After Upjohn, the conclusion was soon drawn in Dutch legal literature that the method of review applied by Dutch administrative law courts was adequate. The Community courts themselves sometimes administer the test of reasonableness with respect to the facts, whereas the Raad van State nearly always subjects the facts to a full test and therefore, it was concluded, that the Raad van State provides the more legal protection. A violation of the principle of effective legal protection by the Dutch administrative law courts seems highly unlikely in this light. This contribution, though, does not endorse the conclusion that the Raad van State sets a higher standard of review. This contribution has shown that the CFI has intensified its application of the test of reasonableness in respect of factual assessments. At this juncture, the Community courts very accurately review whether the administration's opinion on the facts is based on sufficiently sound evidence. It appears that the Raad van State does not carry out such intensive review, as is shown by both the reasons underlying the decision and the empirical investigation of the review of facts on appeal.9 ${ }^{1}$

Accordingly, the question arises whether it is permissible that the national methods of review are less far-reaching than the methods of review applied by the Community courts in similar cases. In principle, this question should be answered in the affirmative. The method of review is part of the Member States' procedural autonomy. Consequently, it appears that the reasoning in Upjohn cannot be applied a contrario. Nevertheless, an overly restricted national test of the factual assessments in cases that involve EC law may eventually lead to a violation of the principle of effective legal protection. Such a violation will not easily be established, as must be recognised. The question arises, however, whether there are sound arguments for the national and the Community courts to review in different ways. For both legal orders, arguments are advanced in favour of the intensity of review required. For the most part, these arguments are similar: the separation of powers preventing the courts from establishing the facts themselves, the risk of overburdening the courts, the need for effective legal protection of interested parties and the need for the administration being effectively checked. At present, the Community courts have struck a balance based on these arguments that differs from that of the Dutch administrative law courts.

Arguments may be raised to explain this difference. The CFI applies an intensive test, after which an appeal may be filed with the ECJ. The comparison between the Raad van State and the CFI is not on an equal par, as the former renders a decision in the last instance and is allocated a different task for that reason - though it also deals with questions of fact. However, the counterargument can be advanced that the ECJ supports the CFI and specifies the requirements that the judicial review of fact-finding should meet as

9I Barkhuysen, Damen et al. (2007). 
well. The Raad van State hardly provides any direction to the district courts with respect to the use of their investigative powers and on how to review the assessment of the facts..$^{2}$ One could also argue that the intensified review of facts in EC law has been most apparent in competition law. The competent Dutch tribunal in that field tailored its test to the standard of the CFI. The importance of the interests at stake in competition law affects the application of the standard of review, resulting in lengthy reasoning in the court's judgments. There is definitely some truth in this, but, still, in national law there are cases where the interests are of similar weight. Moreover the intensified review of the Community courts is also noticeable in other fields of law. Another difference may lie with the procedural rights of interested parties in the adjudication process. Public consultation rights are in general less developed in the Community legal order compared to that of the GALA. Two conclusions can be drawn from this observation. On the one hand, one could argue that interested parties need less intensive review in national court proceedings, because their interests are better protected in the preliminary stage. On the other hand, one can also argue that, as interested parties have been granted participation rights, intensive legal review is appropriate. In this manner, it is guaranteed that the administration will take public consultation and the hearing of interested parties particularly seriously without just confining itself to reviewing procedural safeguards. In addition, the participation procedure provides for a great deal of material, which enables the courts to review the fact-finding intensively. ${ }^{93}$ Democratic control is an important difference in the national and Community legal order as well. I believe that this point, which in itself is relevant, is of limited significance to the fact-finding process. ${ }^{94}$ In principle, fact-finding is not the domain of politics. Insofar as policy considerations play a part in fact-finding, as they may in the case of complex facts based on expertise, parliamentary control will be almost non-existent, precisely because of the required expertise which Parliament lacks as well. The above variety of arguments do not automatically result in a single review method, but all in all, it is difficult to defend that the methods of review in a national and Community context should differ to a considerable degree. The question arises why the Community courts chose to review fact-finding more intensively in order to achieve a different balance in these arguments. Craig refers to factors such as the establishment of the CFI, the increasing need for effective control of the administration after persistent criticism of the legitimacy of the EU, the situation that the EU is now so firmly based that it can stand an annulment and the need to compensate the lack of participation rights of interested parties in the courts. ${ }^{95}$ These factors cannot be simply translated into the national

\footnotetext{
92 Barkhuysen, Damen et al. (2007), p. 69.

93 Cf. Craig (2006), p. 480.

94 Schuurmans (2005), p. 280. Cf. Caranta (2008), p. 195-196.

95 Craig (2006), p, 480 and 48I.
} 
context. Nevertheless, I think it is a good idea to focus the national debate on enhancing the effectiveness of legal protection and a more definitive dispute resolution regime on the developments that the intensity of review in EC law has undergone. ${ }^{96}$

Despite the above arguments, the Dutch administrative law courts will not easily run the risk of withholding citizens effective legal protection as a result of their method of review. Nevertheless, the courts should not deal with the review of facts too easily. If the national courts subject the fact-finding in a decision based on EC law to a test of reasonableness, there is a risk that they fail to recognise a violation of EC law. If the violation is established, there are circumstances in which the Member State may run the risk of being held liable for errors by courts in applying EC law. In Traghetti97 the ECJ emphasizes that the assessment of facts and evidence by the courts are an essential part of their task of administering justice. A very limited review of fact-finding may involve the risk of the courts making an error in reviewing the facts and evidence, for which the Member State may be held liable. For this reason, shaping and developing the national duty of due care test is quite important. Legal practitioners and scholars could use EC case law to give more substance to the review of the facts in national administrative law procedures. A more uniformed review standard could enhance the harmonisation and implementation of Community law.

$9^{6}$ Caranta's (2006) criticism on conceptual sloppiness of the Community courts on discretion in complex factual assessments I do not subscribe. Partly because in comparison to Dutch law courts the Community case law is more consistent, partly because the portrayal of the Glaxo case (Case T-I68/or GlaxoSmithKline Services Unlimited v. Commission [2006] ECR II-2969) is in my opinion not in line with para. 244.

97 Case C-I73/03 Traghetti del Mediterraneo [2006] ECR I-5I77, at para. 37 to 40. 